\title{
CLINICAL AND LABORATORY STUDIES ON EMACIATION AND ILL-THRIFTINESS IN CATTLE AT ASWAN GOVERNORATE
}

\author{
MOHAMED, E.A.; NOUR, S.Y. and ISMAIL, M.N
}

Dept. of Animal Medicine, Fac. of Vet. Med-South Valley Univ.

Email: N/A

\begin{tabular}{|c|c|}
\hline & ABSTRACT \\
\hline Received at: 16/12/2013 & $\begin{array}{l}\text { Cattle has an economic importance in Aswan governorate, hence it considered the } \\
\text { main source of income for most farmers. Emaciation in cattle was the main } \\
\text { complain mentioned by many cattle breeders. The aim of the present work is to } \\
\text { evaluate the relation between emaciation as a clinical sign and the haematological } \\
\text { and biochemical parameters in blood serum of cattle. } 160 \text { emaciated Cows, } 1->5 \\
\text { years old and } 20 \text { clinically healthy cows selected from } 19 \text { villages at Edfu district } \\
\text { constitute the basis of this work. The clinical examination of emaciated cows } \\
\text { revealed poor body condition, debility, alopecia, rough dry hair coat and pale } \\
\text { mucous membrane. Faecal examination of the emaciated cows revealed the } \\
\text { presence of fasciola gigantica ( } 8 \text { cases), paramhistomum cervi (13 cases), eggs } \\
\text { and/or larvae of gastrointestinal nematodes ( } 56 \text { cases). All values of total } \\
\text { erythrocytes count, haemogloloin, packed cells volume and total leucocytes count } \\
\text { were decreased in all emaciated cows at all ages. Marked drop in values of these } \\
\text { parameters were recorded in parasitic emaciated cases. Marked drop with slight } \\
\text { variations in the values of blood serum Ca, P, Mg, Cu and Zn was recorded in all } \\
\text { emaciated animals whether parasitic or non-parasitic (infested). Significant } \\
\text { decrease in total serum protein and albumin was recorded in the emaciated cows. } \\
\text { Marked rise in blood serum values of AST and ALT in animals with emaciation } \\
\text { irrespective of ages or parasitic infestation, was noticed. }\end{array}$ \\
\hline
\end{tabular}

Key words: Clinical studies, Emaciation, Aswan, Cattle.

\section{INTRODUCTION}

Cattle has an economic importance in the world as they play a great role in meat, milk and leather productions (FAO, 2008).

Poor growth and ill-thriftiness in livestock animals were considered the main complain among farmers in Upper Egypt. Bad or inadequate feeding nutrients, deficiency of macro and micro elements, improper housing or management, and the impact of internal and external parasites were incriminated as the most probable causes of such conditions (Sadiek, 2001). Changes in appetite, skin hair coat, mucous membranes, rumen motilities and sometimes body temperature were previously reported (Radostits et al., 2006).

The present work was desingned to investigate the relationship between emaciation and ill-thriftiness in cows and the associated changes in clinical, haematological and some biochemical parameters.

\section{MATERIALS and METHODS}

\section{1- Animals:-}

Animals of this work were belonged to Edfu district, Aswan Governorate, A.R. Egypt. From the great number of cases in 19 villages showing the clinical signs of rough hair coat, pale mucous membrane, debility and ill-thriftiness, 160 non-pregnant dry cows were chosen. 20 healthy cows as confirmed by clinical and laboratory means were used as control.

Animals were classified into three groups according to their ages (1- $<3,3-5$ and more than 5 years old). Careful clinical examination was carried out on each clinically diseased case.

\section{2- Feeding condition and drinking water:-}

Most of these animals feed on Trifolium Alexandrium (Barseen), sugar cane leaves, Darawa and wheat straw.

The sourre of drinking water for these animals was water channels which connected with River Nile. 


\section{3- Samples and Methods:- A-Blood Samples:-}

Two blood samples were collected from each animal, one with EDTA as anticoagulant and the other without anticoagulant for obtaining clear serum. The serum samples were kept in deep freze at $-20^{\circ} \mathrm{C}$ until assayed for some biochemical analysis. The haemogram was studied after Coles (1986).

Blood serum calcium (mmol/L), inorganic phosphorus $(\mathrm{mmol} / \mathrm{L})$, magnesium $(\mathrm{mmol} / \mathrm{L})$, total protein $(\mathrm{g} / \mathrm{L})$, albumin $(\mathrm{g} / \mathrm{L})$, Aspartate amino transferase (AST, U/l) and Alanine amino transferase (ALT, U/l) were estimated colormetrically using test kits supplied by Biomereux, Bains, France and the use of spectrophotometer (uv under score 1201-vs spectrophotometer, SHIMADZY).

Blood serum copper (ppm) and zinc (ppm) concentration were determined by computerized flame atomic absorption (model GBC 906 AA. Australia). The instrument automatically estimate three readings and calculate the average value.

\section{B- Faecal Samples:-}

The faecal samples were collected directly from the rectum, wrapped in clean plastic sacs and carried to the laboratory to perform the required techniques for microscopic examination for internal parasitism according to Coles (1986).

\section{4- Statistical Analysis:-}

Statistical analysis of the obtained data were performed according to Borenstein et al. (1997).

\section{RESULTS}

\section{1- Clinical Findings:-}

The emaciated cows showed dry leathery skin. Hair coat was poor and rough. Alopecia and keratinization of the skin was observed in some animals. Paleness of the mucous membranes in most of emaciated animals and porcelain white in those infested with helminthes. Most cows infested with gastrointestinal parasites showed anorexia, depression, wasting, anaemia and diarrhea. Rumen motility was 1-2 contractions per minute in most examined animals. The rectal temperature ranged between $37.8^{\circ} \mathrm{C}$ $38.5^{\circ} \mathrm{C}$.

\section{2- Faecal Examination:-}

Microscopic examination of the faecal samples of diseases cases revealed the presence of eggs of some trematodes such as Fasciola gigantica (8 cases) and paramphistomum Cervi (13 cases). Also many emaciated cases showed the presence of either eggs or larval stages in their faeces that denotes gastrointestinal parasitism.

\section{3- Haematological Findings:-}

The obtained data of Hb, TEC, PCV and TLC of this work were arranged in tables 1 and 2.

\section{4- Blood Serum Biochemical Findings:-}

a- The obtained data of $\mathrm{Ca}, \mathrm{P}, \mathrm{Mg}, \mathrm{Cu}$ and $\mathrm{Zn}$ of the present work were recorded in tables 3 and 4 .

b- The obtained data of TP, Alb., AST and ALT were present in tables 5 and 6 .

Table 1: Mean values \pm SD of Haemogram in healthy control and emaciated cows at different ages.

\begin{tabular}{|c|c|c|c|c|c|c|}
\hline \multirow{2}{*}{$\begin{array}{c}\text { Blood } \\
\text { parameters }\end{array}$} & \multicolumn{2}{|r|}{ 1- 3 years } & \multicolumn{2}{|c|}{ 3-5 years } & \multicolumn{2}{|c|}{$>5$ years } \\
\hline & $\begin{array}{c}\text { Control } \\
\text { (7) }\end{array}$ & $\begin{array}{c}\text { Emaciated } \\
\text { (47) }\end{array}$ & $\begin{array}{c}\text { Control } \\
\text { (5) }\end{array}$ & $\begin{array}{c}\text { Emaciated } \\
\text { (39) }\end{array}$ & $\begin{array}{c}\text { Control } \\
\text { (8) }\end{array}$ & $\begin{array}{c}\text { Emaciated } \\
\text { (74) }\end{array}$ \\
\hline $\mathrm{Hb}(\mathrm{G} / \mathrm{L})$ & $138.0 \pm 13.03$ & $120.47 \pm 26.77$ & $132.5 \pm 20.53$ & $111.00 \pm 16.51$ & $130.00 \pm 20.00$ & $113.72 \pm 15.67$ \\
\hline TEC(T/L) & $8.54 \pm 0.99$ & $7.05 \pm 2.047$ & $7.80 \pm 1.07$ & $6.15 \pm 1.50$ & $7.50 \pm 1.03$ & $5.80 \pm 1.23$ \\
\hline PCV (\%) & $34.87 \pm 2.46$ & $30.87 \pm 3.56$ & $32.10 \pm 2.80$ & $28.47 \pm 3.10$ & $31.81 \pm 3.6$ & $28.06 \pm 3.05$ \\
\hline TLC(G/L) & $8.97 \pm 1.18$ & $7.80 \pm 2.72$ & $8.20 \pm 1.63$ & $6.9 \pm 1.59$ & $7.6 \pm 1.50$ & $5.95 \pm 2.07$ \\
\hline
\end{tabular}

Total No. of samples from control animals $=20$, Total No. of included emaciated animals $=160, \pm \mathbf{S D}=$ standard deviation 
Table 2:- Mean values \pm SD of Haemogram in control healthy and helminths nfested and non-infested emaciated cows at different ages.

\begin{tabular}{|c|c|c|c|c|c|c|c|c|c|}
\hline \multirow{4}{*}{$\begin{array}{c}\text { Blood } \\
\text { parameters }\end{array}$} & \multirow{4}{*}{$\begin{array}{c}\text { Control } \\
7\end{array}$} & $<3$ yea & & & \multicolumn{2}{|c|}{ 3-5 years } & \multicolumn{3}{|c|}{$>5$ years } \\
\hline & & \multicolumn{2}{|c|}{ Emaciated } & \multirow{3}{*}{$\begin{array}{c}\text { Control } \\
5\end{array}$} & \multicolumn{2}{|c|}{ Emaciated } & \multirow{3}{*}{$\begin{array}{c}\text { Control } \\
8\end{array}$} & \multicolumn{2}{|c|}{ Emaciated } \\
\hline & & $\mathbf{P}$ & $\mathbf{N}$ & & $\mathbf{P}$ & $\mathbf{N}$ & & $\mathbf{P}$ & $\mathbf{N}$ \\
\hline & & 23 & 12 & & 21 & 10 & & 34 & 19 \\
\hline \multirow{2}{*}{ Hb (G/L) } & 138 & $96.3^{*}$ & 125.3 & 132.5 & $93.75^{* *}$ & 117 & 130 & 96.87 & 113.9 \\
\hline & \pm 13.03 & \pm 22.6 & \pm 26.7 & \pm 20.52 & \pm 17.67 & \pm 11.56 & \pm 20 & \pm 9.76 & \pm 11.44 \\
\hline \multirow{2}{*}{ TEC(T/L) } & 8.54 & $5.43^{*}$ & 7.78 & 7.80 & $5.08^{* *}$ & 6.35 & 7.50 & $5.31^{*}$ & 6.24 \\
\hline & \pm 0.99 & \pm 1.97 & \pm 1.82 & \pm 1.07 & \pm 1.08 & \pm 1.04 & \pm 1.04 & \pm 1.26 & \pm 0.96 \\
\hline \multirow{2}{*}{ PCV (\%) } & 34.87 & $27.08^{*}$ & 30.93 & 32.1 & $25.93^{*}$ & 28.62 & 31.81 & $26.21^{*}$ & 29.09 \\
\hline & \pm 2.46 & \pm 3.94 & \pm 2.71 & \pm 2.8 & \pm 4.57 & \pm 1.84 & \pm 3.6 & \pm 3.3 & \pm 2.65 \\
\hline \multirow{2}{*}{ TLC(G/L) } & 8.97 & 6.42 & 7.15 & 8.20 & 7.1 & 6.93 & 7.60 & 5.14 & 5.56 \\
\hline & \pm 1.18 & \pm 1.67 & \pm 2.55 & \pm 1.63 & \pm 1.59 & \pm 1.36 & \pm 1.50 & \pm 1.61 & \pm 1.45 \\
\hline
\end{tabular}

$\mathbf{C}=$ Control $\mathbf{P}=$ Positive helminth infestation (emaciated cows) $* \mathbf{P}<\mathbf{0 . 0 5} * * \mathbf{P}<\mathbf{0 . 0 1}$

$\mathbf{N}=$ Negative helminth infestation (emaciated cows), $\pm \mathbf{S D}=$ Standard deviation

Tables 3: Mans values \pm SD of blood serum Macro and Micro inorganic elements in healthy control and emaciated cows at different ages.

\begin{tabular}{|c|c|c|c|c|c|c|}
\hline \multirow{2}{*}{$\begin{array}{c}\text { Blood } \\
\text { parameters }\end{array}$} & \multicolumn{2}{|c|}{$1-<3$ years } & \multicolumn{2}{|c|}{ 3-5 years } & \multicolumn{2}{|c|}{$>5$ years } \\
\hline & $\begin{array}{l}\mathrm{C} \\
(7)\end{array}$ & $\begin{array}{c}E \\
(47)\end{array}$ & $\begin{array}{l}\mathrm{C} \\
(5)\end{array}$ & $\begin{array}{c}E \\
(39)\end{array}$ & $\begin{array}{l}\mathrm{C} \\
(8)\end{array}$ & $\begin{array}{c}\mathbf{E} \\
(74)\end{array}$ \\
\hline Calcium & 2.32 & $1.11^{* *}$ & 2.04 & 1.57 & 1.92 & 1.35 \\
\hline (m.mol/L) & \pm 0.64 & \pm 0.56 & \pm 0.78 & \pm 0.88 & \pm 0.24 & \pm 0.66 \\
\hline Phosphorus & 1.62 & 1.34 & 1.51 & 1.19 & 1.47 & 1.06 \\
\hline (m.mol/L) & \pm 0.36 & \pm 0.74 & \pm 0.4 & \pm 0.62 & \pm 0.25 & \pm 0.47 \\
\hline Magnesium & 0.71 & 0.53 & 0.69 & 0.66 & 0.68 & 0.49 \\
\hline (m.mol/L) & \pm 0.17 & \pm 0.24 & \pm 0.13 & \pm 0.19 & \pm 0.2 & \pm 0.21 \\
\hline Copper & 1.05 & 0.69 & 0.99 & 0.73 & 0.97 & 0.72 \\
\hline (ppm) & \pm 0.11 & \pm 0.32 & \pm 0.08 & \pm 0.33 & \pm 0.2 & \pm 0.26 \\
\hline Zinc & 1.31 & 0.54 & 1.26 & 0.71 & 1.33 & 0.45 \\
\hline (ppm) & \pm 0.22 & \pm 0.46 & \pm 0.30 & \pm 0.54 & \pm 0.32 & \pm 0.33 \\
\hline
\end{tabular}

$\mathbf{S D}=$ stand deviation, $\quad * * \mathrm{p}<0.01$

$\mathbf{C}=$ healthy control cows,$\quad \mathbf{E}=$ emaciated cows 
Tables 4: Mean values \pm SD of blood serum macro and micro inorganic element in healthy control and helminths infested and non-infested emaciated cows at different ages.

\begin{tabular}{|c|c|c|c|c|c|c|c|c|c|}
\hline \multirow{4}{*}{$\begin{array}{c}\text { Blood } \\
\text { parameters }\end{array}$} & \multicolumn{3}{|c|}{$1-<3$ years } & \multicolumn{3}{|c|}{ 3-5 years } & \multicolumn{3}{|c|}{$>5$ years } \\
\hline & \multirow{3}{*}{$\begin{array}{c}\text { Control } \\
7\end{array}$} & \multicolumn{2}{|c|}{ Emaciated } & \multirow{3}{*}{$\begin{array}{c}\text { Control } \\
5\end{array}$} & \multicolumn{2}{|c|}{ Emaciated } & \multirow{3}{*}{$\begin{array}{c}\text { Control } \\
8\end{array}$} & \multicolumn{2}{|c|}{ Emaciated } \\
\hline & & $\begin{array}{l}\mathbf{P} \\
\end{array}$ & $\mathbf{N}$ & & $\begin{array}{l}\mathbf{P} \\
\end{array}$ & $\mathbf{N}$ & & $\begin{array}{l}\mathbf{P} \\
\end{array}$ & $\mathbf{N}$ \\
\hline & & 23 & 12 & & 21 & 10 & & 34 & 19 \\
\hline $\begin{array}{l}\text { Calcium } \\
\text { (m.mol/L) }\end{array}$ & $\begin{array}{c}2.32 \\
\pm 0.78\end{array}$ & $\begin{array}{c}1.02 \\
\pm 0.33\end{array}$ & $\begin{array}{l}1.26 \\
\pm 0.8\end{array}$ & $\begin{array}{c}2.04 \\
\pm 0.78\end{array}$ & $\begin{array}{c}1.3 \\
\pm 1.02\end{array}$ & $\begin{array}{c}1.86 \\
\pm 1.05\end{array}$ & $\begin{array}{c}1.92 \\
\pm 0.42\end{array}$ & $\begin{array}{c}1.43 \\
\pm 0.71\end{array}$ & $\begin{array}{c}1.47 \\
\pm 0.78\end{array}$ \\
\hline $\begin{array}{l}\text { Phosphorus } \\
\text { (m.mol/L) }\end{array}$ & $\begin{array}{c}1.62 \\
\pm 0.36 \\
\end{array}$ & $\begin{array}{c}1.08 \\
\pm 0.40\end{array}$ & $\begin{array}{c}1.17 \\
\pm 0.66\end{array}$ & $\begin{array}{c}1.51 \\
\pm 0.39 \\
\end{array}$ & $\begin{array}{c}1.06 \\
\pm 0.72 \\
\end{array}$ & $\begin{array}{c}1.18 \\
\pm 0.58\end{array}$ & $\begin{array}{c}1.47 \\
\pm 0.25\end{array}$ & $\begin{array}{c}1.09 \\
\pm 0.56\end{array}$ & $\begin{array}{c}1.11 \\
\pm 0.41\end{array}$ \\
\hline $\begin{array}{l}\text { Magnesium } \\
\text { (m.mol/L) }\end{array}$ & $\begin{array}{c}0.71 \\
\pm 0.17\end{array}$ & $\begin{array}{c}0.46 \\
\pm 0.21\end{array}$ & $\begin{array}{c}0.48 \\
\pm 0.23\end{array}$ & $\begin{array}{c}0.69 \\
\pm 0.13\end{array}$ & $\begin{array}{c}0.6 \\
\pm 0.29\end{array}$ & $\begin{array}{c}0.66 \\
\pm 0.17\end{array}$ & $\begin{array}{c}0.68 \\
\pm 0.20\end{array}$ & $\begin{array}{c}0.48 \\
\pm 0.21\end{array}$ & $\begin{array}{c}0.52 \\
\pm 0.24\end{array}$ \\
\hline $\begin{array}{l}\text { Copper } \\
\text { (ppm) }\end{array}$ & $\begin{array}{c}1.05 \\
\pm 0.11\end{array}$ & $\begin{array}{l}0.65 \\
\pm 0.4\end{array}$ & $\begin{array}{l}0.79 \\
\pm 0.3\end{array}$ & $\begin{array}{c}0.99 \\
\pm 0.08\end{array}$ & $\begin{array}{c}0.57 \\
\pm 0.34\end{array}$ & $\begin{array}{c}0.88 \\
\pm 0.27\end{array}$ & $\begin{array}{c}0.97 \\
\pm 0.27\end{array}$ & $\begin{array}{c}0.58 \\
\pm 0.33\end{array}$ & $\begin{array}{c}0.84 \\
\pm 0.15\end{array}$ \\
\hline $\begin{array}{l}\text { Zinc } \\
\text { (ppm) }\end{array}$ & $\begin{array}{c}1.31 \\
\pm 0.22\end{array}$ & $\begin{array}{c}0.54 \\
\pm 0.50\end{array}$ & $\begin{array}{c}0.67 \\
\pm 0.59\end{array}$ & $\begin{array}{c}1.26 \\
\pm 0.30\end{array}$ & $\begin{array}{c}0.64 \\
\pm 0.63\end{array}$ & $\begin{array}{c}0.79 \\
\pm 0.56\end{array}$ & $\begin{array}{c}1.33 \\
\pm 0.32\end{array}$ & $\begin{array}{c}0.23 \\
\pm .016\end{array}$ & $\begin{array}{c}0.33 \\
\pm 0.15\end{array}$ \\
\hline
\end{tabular}

$\mathbf{C}=$ healthy control cows, $\quad \mathbf{P}=$ positive helimenths in emaciated cows

$\mathbf{N}=$ Negative helmintths in emactiated cows, $* * \mathrm{P}<0.05$

Table 5: Mean values \pm SD of blood serum biochemicals in healthy control and emaciated cows at different ages.

\begin{tabular}{|c|c|c|c|c|c|c|}
\hline \multirow[b]{2}{*}{ Blood parameters } & \multicolumn{2}{|c|}{$1-<3$ years } & \multicolumn{2}{|c|}{ 3-5 years } & \multicolumn{2}{|c|}{$>5$ years } \\
\hline & $\begin{array}{c}\text { Control } \\
\text { (7) }\end{array}$ & $\begin{array}{c}\text { Emaciated } \\
(47)\end{array}$ & $\begin{array}{c}\text { Control } \\
\text { (5) }\end{array}$ & $\begin{array}{c}\text { Emaciated } \\
\text { (39) }\end{array}$ & $\begin{array}{l}\text { Control } \\
\text { (8) }\end{array}$ & $\begin{array}{c}\text { Emaciated } \\
\text { (74) }\end{array}$ \\
\hline \multirow{2}{*}{ T.P (Gm/L) } & 77.29 & $45.48^{* * *}$ & 79.60 & $43.12^{* * *}$ & 84.33 & $45.50^{* * *}$ \\
\hline & \pm 14.5 & \pm 14.48 & \pm 20.36 & \pm 13.60 & \pm 8.14 & \pm 13.11 \\
\hline \multirow{2}{*}{ Albumin (Gm/L) } & 39.07 & $20.60^{* * *}$ & 40.83 & $22.97^{*}$ & 43.75 & $24.7^{*}$ \\
\hline & \pm 5.75 & \pm 8.5 & \pm 6.27 & \pm 9.80 & \pm 15.06 & \pm 8.31 \\
\hline \multirow{2}{*}{$\operatorname{AST}(u / L)$} & 34.75 & 71.10 & 31.00 & 81.50 & 33.50 & 64.21 \\
\hline & \pm 9.4 & \pm 40.45 & \pm 5.33 & \pm 56.95 & \pm 15.74 & \pm 45.83 \\
\hline \multirow{2}{*}{$\operatorname{ALT}(\mathbf{u} / \mathbf{L})$} & 20.57 & 29.75 & 15.5 & 27.07 & 16.00 & 29.2 \\
\hline & \pm 8.2 & \pm 16.54 & \pm 3.31 & \pm 12.37 & \pm 6.55 & \pm 13.4 \\
\hline
\end{tabular}

$\mathbf{T} . \mathbf{P}=$ total protein, $\pm \mathbf{S D}=$ standard deviation

$*=\mathrm{p}<0.05 \quad * *=\mathrm{p}<0.01 \quad * * *=\mathrm{p}<0.001$

Table 6: Mean values \pm SD of blood serum biochmicals in healthy control and Helminths infested and noninfested emaciated cows at different ages.

\begin{tabular}{|c|c|c|c|c|c|c|c|c|c|}
\hline \multirow{4}{*}{$\begin{array}{c}\text { Blood } \\
\text { parameters }\end{array}$} & \multirow{4}{*}{$\begin{array}{c}\text { Control } \\
7\end{array}$} & \multicolumn{2}{|c|}{$1-<3$ years } & & \multicolumn{2}{|c|}{ 3-5 years } & \multicolumn{3}{|c|}{$>5$ years } \\
\hline & & \multicolumn{2}{|c|}{ Emaciated } & \multirow{3}{*}{$\begin{array}{c}\text { Control } \\
5\end{array}$} & \multicolumn{2}{|c|}{ Emaciated } & \multirow{3}{*}{$\begin{array}{c}\text { Control } \\
8\end{array}$} & \multicolumn{2}{|c|}{ Emaciated } \\
\hline & & $\mathbf{P}$ & $\mathbf{N}$ & & $\mathbf{P}$ & $\mathbf{N}$ & & $\mathbf{P}$ & $\mathbf{N}$ \\
\hline & & 23 & 12 & & 21 & 10 & & 34 & 19 \\
\hline \multirow{2}{*}{ T.P $(\mathrm{Gm} / \mathrm{L})$} & 77.30 & $40.6^{* * *}$ & $48.3^{* *}$ & 79.6 & $41.7^{* * *}$ & $50.2^{* *}$ & 84.33 & $41.2^{* *}$ & $47.7^{*}$ \\
\hline & \pm 14.5 & \pm 12.2 & \pm 12.8 & \pm 20.4 & \pm 12.4 & \pm 18.2 & \pm 8.14 & \pm 12.7 & \pm 13.6 \\
\hline \multirow{2}{*}{$\begin{array}{l}\text { Albumin } \\
(\mathrm{Gm} / \mathrm{L})\end{array}$} & 39.7 & $17.7^{* * 2}$ & $20.04^{* *}$ & 40.83 & $19^{*}$ & $21.28^{*}$ & 43.75 & $21.13^{*}$ & 23.32 \\
\hline & \pm 5.75 & \pm 6.02 & \pm 5.8 & \pm 6.3 & \pm 8.4 & \pm 9.6 & \pm 15.1 & \pm 7.1 & \pm 5.23 \\
\hline \multirow{2}{*}{$\operatorname{AST}(\mathrm{u} / \mathrm{L})$} & 34.8 & 89.7 & 52.5 & 31.0 & $110.9^{*}$ & 49.5 & 33.5 & 75.9 & 46.2 \\
\hline & \pm 9.4 & \pm 44.9 & \pm 425.3 & \pm 4.86 & \pm 72.8 & \pm 21.2 & \pm 5.74 & \pm 53.5 & \pm 22.3 \\
\hline \multirow{2}{*}{$\operatorname{ALT}(\mathrm{u} / \mathrm{L})$} & 20.57 & 31.15 & 28.5 & 15.5 & 26.14 & 23.3 & 16.0 & 31.14 & 26.76 \\
\hline & \pm 8.2 & \pm 17.8 & \pm 15.9 & \pm 3.31 & \pm 6.89 & \pm 15.3 & \pm 6.5 & \pm 12.0 & \pm 0.99 \\
\hline
\end{tabular}

$\pm \mathbf{S D}=$ stand deviation. $*=\mathrm{p}<0.05 \quad * *=\mathrm{p}<0.01 \quad * * *=\mathrm{p}<0.001$

$\mathbf{T} . \mathbf{P}=$ total protein. A.S.T $=$ aspartate amino transferase.

A.L.T $=$ alanine amino tranferase. 


\section{DISCUSSION}

Cattle are considered the main integral part of the farming system for small farmers in Aswan (Egypt). In spite of their importance, there is a gap between their actual and potential productivity.

\section{1- Clinical examination:-}

Animals of the present work suffered from emaciation, ill-thriftiness, dullness, roughness of skin hair coat, pale mucous membrane, deprived appetite, Poor body condition, weakness and soft faeces or even diarrhea. These signs were encountered in malnutrition and infestion with gastrointestinal parasites (Hussien, 2005).

The recorded rumen motility and body temperature of the diseased cases simulated that reported by Radostits et al. (2006).

\section{2- Haematological Findings:-}

Generally, the haemogram reflects the degree of health condition in animals (Coles, 1986). There was insignificant decrease the mean values of $\mathrm{Hb}$, TEC, PCV and TLC in emaciated cows at all ages in comparison with clinically healthy animals (table 1). This decrease in the heamatological parameters may partly caused by malnutrition and infestation with helminths (Radostits et al., 2006). Also, the decrease in TLC in emaciated cases could be attributed to impairment of several aspects of immunity (Fekete and Kellems, 2007).

Table 2 showed that, there was a significant decrease in the values of $\mathrm{Hb}$, TEC and PCV in emaciated cows infested with helminths in all age groups comparing with control animals. Our results were in agreement with Taha, (1991) and Ibrahim et al. (1992) who attributed the drop in the values to malabsorption of nutrients particularly protein. More recent studies have reported contradictory effects of gastrointestinal parasites on apparent digestibility of organic matter and crude protein (Xiao and Gibbs, 1992). Suppression of bone marrow function possibly as a result of toxic substances secreted by parasites act directly on bone marrow lead to suppression of erythropoietin or indirectly by injuries action on another important organ as liver (Mohamed,1998). The cause also may be due to blood sucking immature parasites and the haemorrhage caused by deep penetration into the mucosa and submucosa together with anorexia (Soulsby, 1982).

Lowered haematological parameters in non-infested emaciated cows in all groups (table, 2) could be attributed to insufficient intake and mineral deficiency (Sharma et al., 2005). The helminths infested emaciated animals showed reduction in TLC than the non-infested emaciated cows in age group 1$<$ 3years comparing with the clinically healthy animals (table, 2). The obtained results could be attributed to failure of animals to mount a satisfactory immunological response to worm larvae because of protein and mineral deficiency (McClure, 2008), as the parasite interfere with their absorption (Sadiek, 2001).

\section{3- Macro-Elements (Ca, P and Mg):-}

Blood serum minerals, calcium, phosphours and magnesium, generally showed decrease with increasing age beyond one year in healthy control animals (Ndlovu et al., 2009). A suggested explaination is due to that younger animals absorp dietary minerals $(\mathrm{Ca}, \mathrm{P}$ and $\mathrm{Mg})$ more efficiently than older ones (Gurgoze and Icen, 2010).

The age of emaciated animals has a marked effect on the blood serum minerals (table,3), that could be attributed to change in mineral requirements where the young growing animals need more than the older ones (Radostits et al., 2006). Various degrees of reduction in the blood serum values of minerals were reported among all animals ages either parasitic or non-parasitic emaciated cases (table, 4). Collectivally, the decrease in blood serum values of minerals $(\mathrm{Ca}, \mathrm{P}$ and $\mathrm{Mg}$ ) may explained on the basis of malnutrition, reduced absorption and/or retention of minerals particularly in animals with helminths infestations (Sadiek, 2001 and Chorfi et al., 2007).

\section{4- Micro-elements ( $\mathrm{Cu}$ and $\mathrm{Zn})$ :}

There was an obvious but non-significant decrease in the mean values of copper and zinc in emaciated cows in all age groups as compared with normal values (table, 3). Copper deficiency in cattle is characterized by poor growth, anemia, loss of hair and changes in its color as well as poor body condition (Radostits et al., 2006). Also, the obtained results revealed decrease in both blood serum $\mathrm{Cu}$ and $\mathrm{Zn}$ levels in the infested emaciated animals than the non-infested emaciated cases when compared with the control animals (table, 4). This could be attributed to loss of appetite on one hand and loss of blood of the host by parasitic infestation on the other (Kaneko et al., 1997).

\section{5- Liver function tests:}

The emaciated animals (table, 5) showed a significant drop $(p<0.05, p<0.01$ and $p<0.001)$ in both blood serum total protein and albumin values as compared with control ones. This comes in agreement with Coles (1986). The obtained olata (table, 6) showed a decrease of both total protein and albumin in blood serum of parasitic infested emaciated cows when compared with both the noninfested emaciated and control animals. This may attributed to gut nematodes that cause reduction in 
feed intake at one hand and the disturbed protein metabolism on the other, (Coles, 1986).

The recorded mean values of AST and ALT enzymes in blood serum of clinically healthy control cows (table, 5) were similar to Nahed (2010).

Marked non-significant elevation of both AST and ALT enzymes in blood serum of emaciated cows (table, 5) was recorded in all age groups. The recoded elevation was mainly due liver disorders and sometimes muscle injuries (Coles, 1986).

Obvious and sometimes significant elevation of serum AST and ALT enzymes in both parasitized and non-parasitized emaciated animals as compared to the control was reported (table, 6). The changes in levels of these enzymes were due to injuries in the liver cells as well as the toxic effects of gastrointestinal parasites on liver cells (Coles, 1986).

\section{REFERENCES}

Borenstein, M; Rothstein, H. and Cohen, (1997): Sample power statistics 1.0. spss Inc. Chicago.

Chorfi, Y.; Lanevschi, A.; Dupran, P.; Girard, V. and Tremblay, A. (2007): Serum biochemical parameters and embryo production during superovulatory treatment in dairy cattle. Ress. Vet. Sci., 88: 318-321.

Cloes, E.H. (1986): Vterinary clinical pathology, $4^{\text {th }}$ ed. Saunders, Philadelphia, London.

$F A O$, (2008): Website food and Agric. Organization.

Fekete, S.G. and Kellems, R.O. (2007): Interrelationship of feeding with immunity and parasitic infection. A review, Vet Med. 52(4): 131-143.

Gurgoze, S.Y. and Icen, H. (2010): The influence of age on clinical biochemical parameters in pure-bred Arabian Mares. J. equine Vet. Sci., Vol. 30. No. 10.

Hussein, H.A. (2005): Effect of some internal and external parasitic infestation on body condition in cattle with special reference to liver function tests and some trace elements. M.V. Sc., Fac. of Vet. Med., Assiut. Univ.

Ibrahim, A.B.; Gaffar, A.A.; Gameel, A.A.; Nayl, N.M. and E/ Galilan, M. (1992): A note on haemogram of the dromedary camel in Bahrain. Rev. Elev. Med. Vet. Trop. 45: 318-320.

Kaneko, J.J.; Harves, J.W. and Bruss, M.L. (1997): Clinical Biochemistry of Domestic Animals. $5^{\text {th }}$ ed., Academic press, Inc, New York.

McClure, S.J. (2008): How minerals may influence the development and expression of immunity to endoparasites in livestock. Par. Imm. 30: 89-100.

Mohamed, S.S (1998): Some studies on the effects of gastrointestinal parasitism on blood changes in camels with special reference to trace elements. M.V.SC. thesis, Fac. Vet. Med. Ass. Univ.

Nahed, S.T. (2010): Investigation of serum insulin and cortisol concentrations in foot and mouth disease infected cattle in relation to changes in serum biochemical variables and protein elecrophoretic fractionation profile. Global Vteterinaria 4 (5): 450-455.

Ndlovu, T.; Chimonyo, M.; Okoh, A.I.V.; Muchenje, K.D.; Dube, S. and Raats, J.G. (2009: A comparison of nutritionally related blood matebolites among Nguni, bonsmara and Angus steers raised on sweetvels the Vet. J. 179: 273-281.

Radostits, O.M.; Gay, C.C.; Hinchdiff, K.W. and Constable, D.P. (2006): Vet. Med., A textbook, $10^{\text {th }}$ ed., Edinburgh, London, New York.

Sadiek, A.H. (2001): Eimaciation and ill-thrifit in sheep and goats in New- Valley Givernorate. $6^{\text {th }}$. Sci. Cong. of cattle Dis. Nov., 2001.

Sharma, M.C.; Chinmay, J.; Pathak, N.N. and Harzit, K. (2005): Copper status, enzymes, hormone, vitamin and immune function in heifers. Res. Vet. Sci. 79: 113-123.

Soulsby, E.J.L. (1982): Helminth, arthropods and profozoa of domesticated animals $7^{\text {th }}$ ed., Balliere, Tindal and Cassel, London.

Xiao, L. and Gibbs, H.C. (1992): Nutritional and pathophysiologic effects of clinically apparent and subclinical infections of ostertagia ostertagi in calves. Am. J. Vet. Res. 53: 2013-2018.

Taha, A.M. (1991): Clinical, haematological and immunological studies on parasitic anaemia of cattle. M.V.Sc. Fac of Vet. Med. Assiut. Univ. 


\title{
دراسات إكلينكيه ومعمليه عن الهزال والضعف فى الابقار بمحافظة أسوان
}

\author{
عادل السبي احمد ، صفاء يوسف نور ، محمد نور اللدين اسماعيل \\ Email: N/A
}

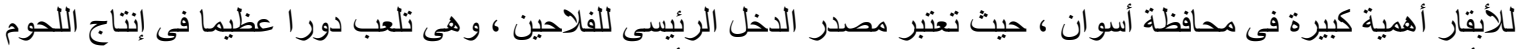

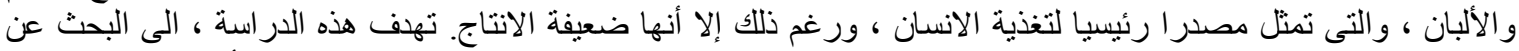

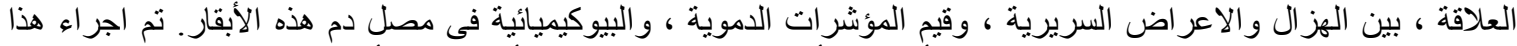

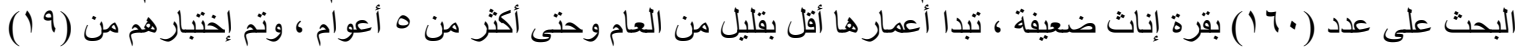

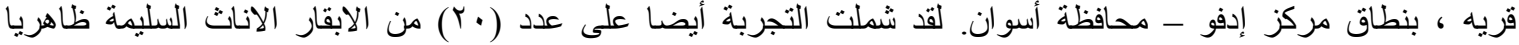

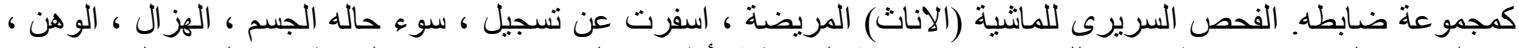

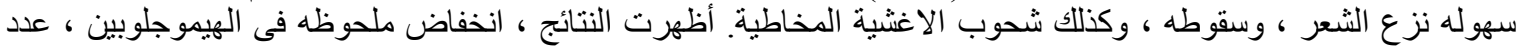

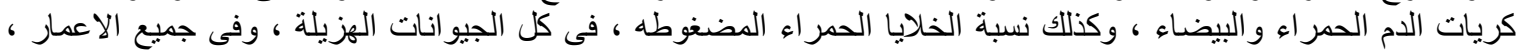

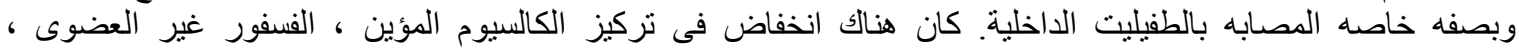

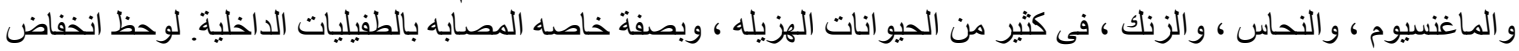

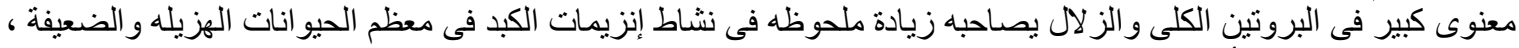

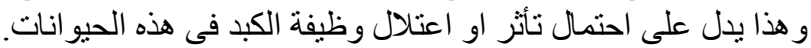

